\title{
Cultural Action Against Hoaks Sociocultural Study of Poetry Anthology in Hoax Poetry by Sosiawan Leak
}

\author{
Mulyono \\ Department of Indonesian Language and Literature, Faculty of Languages and Arts, \\ Universitas Negeri Semarang, Sekaran College, Gunungpati, Semarang \\ \{sendang_bagus@mail.unnes.ac.id\}
}

\begin{abstract}
Hoax spreaders can come from all community, from the poor to the rich community, from low to high intellect community, ordinary commuinty to officials, and so on. The hoax phenomenon at this time has become a matter of great concern and damage to common sense. It is not easy to fight hoaxes. The approach that has been relied on is the general approach. In fact, the practice of a legal approach presupposes a law enforcer with true integrity, it still becomes a hope in this country. So, a cultural approach is needed to invite the community to fight hoaxes. This study examines Sosiawan Leak in the Indonesian literary and reveals Sosiawan Leak's views as outlined in the Hoax Poetry Anthology. The method in this study uses genetic structuralism. There are three stages in conducting research by using the theory and method of genetic structuralism, namely the thesis is an information that is needed in the form of data, the antithesis is the giving of an opinion on reality, this antithesis combines with the thesis and gives an opinion on the reality/ synthesis, and finally the synthesis is in the form of reality and becomes a thesis again. The result of this study is the existence of an action against hoaxes through poetry in the works of Sosiawan Leak
\end{abstract}

Key words: cultural action, hoaxes, genetic structural

\section{Introduction}

The very rapid development of information and communication technology has a major impact on the pattern of human life and behavior. People easily express their opinions, spread them on social media, without thinking about whether their opinions cause problems or not. At first, someone maybe shares opinion is just for fun or wants to show their existence. It is even worse when tells something by lying for certain political interests which makes people believe and deceived.

Hoax spreaders can come from all community, from the poor to the rich community, from low to high intellect community, ordinary community to officials, and so on. The hoax phenomenon at this time has become a matter of great concern and damage to common sense. It is not easy to fight hoaxes. The approach that has been relied on is the general approach. In fact, the practice of a legal approach presupposes a law enforcer with true integrity, it still becomes a hope in this country. So, a cultural approach is needed to invite the community to 
fight hoaxes. Literature is a branch of culture. The existence of a literary work is influenced by the background of the author and the circumstances of the creation of literary works. The emergence of literary communities has become a space for some authors to process and produce literary works. From those communities, some authors became recognized in the literary field. If these authors have the integrity to invite the community to fight hoaxes, it is certainly very effective in raising awareness against hoaxes in the community.

Literary and cultural communities become an event for discussion of various actual life problems. Therefore, this field is related to authorship activities and plays a role in the authorship process. The literary field as a space for authorship becomes an important locus in the process of producing literary works. In other words, background and environment play a big role in its creation. Sosiawan Leak is one of the authors who appeared in the Indonesian literary field from the New Order era to the post-New Order era with his works that spread criticism of social phenomena in Indonesia. Its name is well known with a cultural action with the concept of Poetry Against Corruption.

Besides being an author, Sosiawan Leak is an activist in theater and other cultural activities. Sosiawan Leak's practices outside of his literary works imply his desire to gain a certain position in the Indonesian literary field. At least to maintain its existence in the tight competition with the emergence of productive young authors. The more important is that his works and activities seem to emphasize that authors must be involved in solving the problems of the nation and humanity.

This study examines Sosiawan Leak's struggles in the Indonesian literary field and reveals views as outlined in the Hoax Anthology Anthology. His struggles in the literary and cultural field also have an effect on the color and quality of his works. Several studies that are relevant to the author's study are the research of Riadi, S., \& Emzir, E. entitled Sufistic and Transformative Pedagogic Values in Syaikh Siti Jenar Novel By Agus Sunyoto Genetic Structuralism (2015), research Batool, A., Naheed, R., Khalid, A., Khan, AB, \& Muhammad, SAA entitled Stylistic Analysis of Alfread Tennyson's Poem Tears Idle Tears (2015), Shaikh's research, NU entitled Literary Theory and Criticism: An Unaffordable Buzzword in English Literature (2016), research by Deveson, A. entitled The Limits of Cosmopolitanism in the Poetry of Michael Hofmann (2017), and a research by Ayanto, A., Sudardi, B., Purwasito, A., $\&$ Wakit, A. entitled Social Criticism in the Text Scripture of Dharmasonya (2017).

\section{Research Method}

The method of this study is descriptive-qualitative. According to Goldman, there are three stages in conducting literary research by using genetic structuralism theory. First, the thesis stage is about information that is needed in the form of data. Second, the antithesis stage that is giving an opinion on reality, this antithesis merges with the thesis and provides an opinion on reality. Third, the synthesis stage in the form of reality and becomes to the thesis again. The procedure (method) of genetic structuralism theory for research by Goldman is as follows. a. Literary research is seen from one unity

b. The literary works analyzed are only works that have literary value and have a tension between diversity and unity in a solid unity (a coherent whole).

c. If a unity has been found, then its relationship with social background is analyzed

A strong literary works as stated by Goldman are those that have unity and diversity (complexity), namely there are categories that interrelate with one another that form genetic structuralism, namely; human facts, collective subject (trans individual subject), structure, 
view of understanding, and explanation. It is common for genetic structuralism to be applied to study novels. However, it does not mean that it is closed to the study of poetry. As a genre, poetry is different from novels. Poetry is the most condensed and concentrated form of literature. Poetry is the most dense and concentrated form of literary work. Although it has few words, poetry actually reveals many things (Perrine in Siswantoro 2010: 23).

\title{
3 Discussion
}

\subsection{Hoaxes, a Labyrinth of Victims and Spreaders}

In the poetry anthology of Hoax Poetry, Leak divides 12 episodes with unique names. Watch the episodes of Gagalampus, Cemasmara, Jarahabis, Monsteridiot, Fobiarumah, Bisakandang, Apatiselingkuh, Tubahewan, Kesatriasia, Dioramanegeri, Hidupunah, Puisiserapah. "Hoax Rhymes" is in the episode of Puisiserapah. Analyzing by the name of the episode, it implies the meaning of the poet and even considers his poetry to be swearing or cursing. He cursed people who were victims of hoaxes, then turned into hoax spreaders because of his foolishness.

\author{
HOAX RHYMES \\ headless people \\ cannot keep arguments, facts, and data \\ from the little finger, the elbow, the knee \\ even anal and buttock cleavage; spouting words \\ incarnate provocation magic, agitation lender, \\ also superficiality of conscience \\ spread the philosophy of ignorance and jealous envy \\ without equal \\ ; untraceable in dictionary terms, research treatises, \\ theory, and scientific studies \\ especially the holy book and local wisdom manuscripts. \\ pettiness of the idea is more languish \\ rather than cold, hunger, thirst, \\ even silence \\ headless people \\ get lost in the virtual jungle \\ fall in love with the mass lie, \\ snobby communication, mention, and hate comments \\ as well as selfie affection \\ ; is awara without limits at the end of one's own genitals \\ but sluggish without pulses, air waves, and praise frequencies \\ headless people \\ haunts in cyberspace \\ robed cheap online, armed with freedom \\ stay status, thumbs up, and block dime
}


headless people

assemble a head from the crumbs of civilization

; his eyes screen is faded, his mouth is a rusty keyboard,

his ears are soulless links,

his nose pulls the junk blogs

who spread slander in the ankles

but always splashed with pee

and cum masturbation!

Headless people are people who have no brain (ora duwe utek, tend to be rude, Javanese), people who are unable or unwilling to think, do not maintain honor, do not responsible (hide their identity), do not respect humanity, people who have lost identity. Can not keep an argument is not having clear reasons, without think twice to speak, stupid. Not being able to keep facts means ignoring facts, being managed by emotions/ feelings. Wingka katon kencana, kencana katon wingka. Not being able to keep data shows that they don't use accurate data, talk without data, even if using data, it is hoax data. Can not keep logical truths means not using reasoning power, not scientific thinking, irrational thinking, maybe also being shackled in the realm of mythical thinking

The poem "Hoax Poetry" is very liquid, easy to grasp its meaning, aka communicative. This is certainly very effective as a material for action. The community will easily grasp the message of poetry. Sosiawan Leak conveyed it straightforwardly without eliminating his poetic words as poetry. There is an awareness of rhyme games, there is also hyperbolicism. People without a head / cannot keep arguments, facts, and data / as well as logical truths in their brain/ from their little finger, elbow, knee/ even rectum and buttocks; words spurt/ incarnate provocation magic, mucus agitation (p. 164).

Headless people are hoax spreaders whose identities are unknown, they hide behind fake social accounts or media that are not clearly verified as the validity of their data. Sosiawan Leak continues his line of poetry by "can not keep arguments, facts, and data/ as well as logical truths in his brain/" because in reality they are not facts and are often not built with logical truths or correct thinking.

Pay attention to the following lines: also sometimes consciencel spreading philosophy of foolishness and envy without conter/ cannot be traced in the dictionary of terms, research treatises/theories, and scientific studies/ scriptures and local wisdom. (p. 164)

The following verse above emphasizes that hoax spreaders do not have a good conscience as a community, their conscience is shallow, they cannot think deeply or carefully. They spread lies based on envy. Spreading a philosophy of foolishness is to convey a series of words that seem reasonable and wise, but they are actually stupid. Unfortunately, people like that feel become the truest and the greatest people, win arguments, without a counter. As a hoax, the data submitted cannot be found in various legitimate, valid, or reliable sources, for example research results, scientific studies, or in holy books and local wisdom lontar. Lontar local wisdom that is the noble values of culture. Even more sad, the contents of the holy book are politicized and distorted according to certain purposes.

Hoaxes can occur due to misinformation or disinformation. Misinformation is a wrong information, but the people who share it believe that it is true (falling in love with mass lies). Unfortunately, sometimes they don't realize it, so they become arrogant and readily hate other parties. Meanwhile, disinformation is a wrong information but it is deliberately spread for a specific purpose (headless people in cyberspace/ haunts in cyberspace). In order to convince other parties, sometimes playing in the image (through online), and expressing themselves in 
the name of freedom. Misinformation and disinformation are part of an information disorder. In addition to misinformation and disinformation, there is also such a thing as malinformation, which is true information, but it is used to threaten the existence of a person or group of people with certain identities.

The types of misinformation and disinformation content include: satire or parody, sharing status, thumbs up, and blocking bad story or news. Misleading content, assembles heads of crumbs of civilization, imposter content, fabricated content, false connections, false context content, content that is misleading, and content that is manipulated (manipulated content). However, the term fake news is still more often used by ordinary people. Fake news is wrong news/ information that is spread with the aim of misleading the community for the sake of meeting the personal purposes of the maker. These purposes can be commercial, political, ideological, and others. Fake news includes fake URLs, fake sources, or alternative facts that can be disproved.

Hoax is a lie that is made up in such a way as to cover or divert attention from the truth, which is used for personal gain, both intrinsically and extrinsically. Hoax is information that is manipulated to cover up real information. In other words, hoaxes can be interpreted as an attempt to distort facts using convincing information, but the truth cannot be verified. Hoax can also be interpreted as an act of obscuring the real information, by fulfilling a mass media with the wrong message in order to cover up the correct message. The purpose of deliberate hoaxes is to make people feel insecure, uncomfortable, and confused. In confusion, people will make weak, unconvincing and even misstep decisions.

Overall, Leak actually only highlights that hoax spreaders are stupid people. They are victims of hoaxes, then spread hoaxes or fake news to other people with various interests, motivations, and foolishness. Hoax victims have the potential to spread hoaxes and feel smart and big in cyberspace, but poor in the real world. These hoax victims are constantly spreading hoaxes. That's the foolishness.

\title{
3.2 Rely on Poetry
}

In addition of "Hoax Poetry", in Puisiserapah Episode also contains poetry which titles use the word of poetry or its synonym. Look at the following sentence: "You Record with Poetry", "Poetry, Jungle or Park", "Pale Poetry", "Curse", "On the prayer mat I write a poem", and "I Write Poetry". These poems are often read to accompany the reading of the poem "Hoaks Poetry". The meaning that is implied is quite clear that poetry can be used as a media to get closer the humanity and develop honesty that has imaginative nature. People who do not understand it, accuse it of being just a futile imaginary work. People who are good at poetry are people who cultivate imagination, not people who string lies. Imagination is different from lies

\author{
I WRITE POETRY \\ I write poetry \\ Because conscience must be translated \\ While God has the power to say \\ Then the poet can also compose words \\ Spells out consciousness even if it stops
}

What is meant by translating conscience? Conscience is the voice of the heart, the voice of truth, honesty, beauty, light of divinity. Poetry as a work of art concretizes this. Art strengthen 
something abstract. Thus, poetry becomes a communication phenomenon to convey the message of truth beautifully. Almighty God has spoken of the importance of daring to speak the truth. Poetry as a poet's work, is the result of creative work, a series of creative words of a poet to understand and nurture consciousness even though it may not be as easy as one might imagine. Poets are no different from God's caliphs who have the task of conveying the truth

I write poetry

Although I understand it is meaningless

Because poetry is not a verse of God

The legitimate person who can touch heaven or hell.

Poetry is not a law

Which is sometimes discordant

Take aim at truth and error

In the courtroom

Which is staked by poles

Money

Poetry is not a practical solution to various problems. Poets are aware of that. A hungry person cannot be full with poetry. People who are victims of deception cannot survive with poetry. Poetry cannot change things directly. It is a cultural action, a moral action for building mentality. Poetry does not have the power to judge someone. Nonetheless, poetry is more meaningful than articles in the law which articles are clear, but are often took advantage to get wealth. Aren't the judges who taking advantage of that article a hoax? Poetry is sometimes also more effective as a media to educate community to do good things than preachers who like to speak out about heaven and hell which are unseen.

\section{I write poetry}

Because of the naive anxiety to be silenced

Even though I know

Policy is no longer able to fight shotgun

People or power who like to silence critical thinking are naive. Critical people and intellectuals are restless people. They are not people who are comfortable in the establishment, while the fate of others is unclear. Power (people) who silence restlessness, restlessness because of social inequality, injustice, noise, etc. is naive. It is only done by a tyrannical power. Moral values and the mandate of poetry are policies. However, sometimes these policies are defeated by authoritarian and arbitrary powers

I write poetry

Because verses close to agony

And the law is easier to to be raped

Njelma froth in every corner of the mouths of lions and wolves

Poetry has become an important cultural force when people no longer pay attention to holy scriptures. It is not the verses that are untrue or powerless, but the transmitters of those verses that are not credible in community so that people underestimate the verses. For example, preachers who share hatred, violence, aren't these things actually making community far from the verses and bringing the verses closer to sacredness? It is unfortunate that many preachers 
whose behavior is said to be incompatible with their behavior, they are not able to be good role models.

In connection with the enforcement of regulations and laws, poetry more meaningful because if we hope from the enforcement of laws, it is very small because there is a judicial mafia. Aren't they twisting articles, tweaking the rules, in fact they have also lied? Poetry needs to be present to cure mental illness. Truth is bitter and sometimes it takes a spirit of selfsacrifice to convey it. Persecuted people need to have their fate elevated. The power that is unable to eradicate the wounded, the poor, the sick, the alienated people has actually also made a hoax, because during their campaign they shouted bravely to bring it down. I write poetry/ because wounds have to be healed even in pain

Poetry is a media for humans to become truly human, complete human beings. Humans who have maturity to think, physically and mentally prosperous. I write poetry/ because life must be paid off. The strength of poetry enlightens everything. Maybe it doesn't have a big impact, but at least someone wants to be enlightened.

\subsection{Leak Culture Action: Between Caring and Maintaining Existence}

Sosiawan Leak was born in Solo, September 23, 1967. He completed his studies at the Faculty of Social and Political Sciences, Sebelas Maret University, Surakarta. His writing experience began in 1987. His writing is in the form of poetry, essays, and play scripts. In addition, he is also an actor and director of several theater groups in Solo. Sosiawan Leak prefers to fight in the field of literature rather than engage in politics directly. Leak's view can be observed when he was involved in "A Friend's Story in Solo About Wiji Thukul's Change After Becoming an Activist" (detik.com 2014). To maintain his existence, Leak often went in and out of campus. Students and young people are the potential generation to develop culture. Leak trained to read and write poetry, theater workshops, passed on literary knowledge. The strategy he chose was not to distance himself or build intimacy. For example in the activity at the PGRI Ronggolawe University Tuban held by the Indonesian Language and Literature Study Program Student Association. In this activity he used it to launch books (Rahayu 2016). $\mathrm{He}$ is also involved in "Interfaith Leaders Pray for 7 Pataka Merah Putih Kirab Satu Negeri" (Yogyakarta Kompas.com 2018). Sosiawan Leak was also active in pesantren circles. So, he was also involved in the "Literature Conference" (Alif.id 2018). Isbedy Stiawan ZS (TerasLampung.com 2014) narrated Sosiawan Leak's actions as the commander of the poetry culture movement against corruption.

Some of Leak's steps were conducting poetry reading at Pasau University (2003), University of Hamburg (2003 and 2011), Deutsch Indonesische Gesellschaft, Hamburg (2011), Indonesian Embassy in Berlin (2011), Korea Broadcasting System (KBS) in Seoul, and Hwarang Park 667 in Ansan City (2012). Still in 2012 he did poetry reading with Adam Wideweisch (USA) at the Kalimasada Biltar Cultural House and with South African Poets (Charl-Pierre Naude, Vonani Bila, Mbali Bloom, Rustum Kozain) and German Curator (Indra Wussow) at Jember State University . He conducted an appreciation program for IndonesianGerman literature in Indonesia from 2006 to 2010 with Martin Janskowski and Berthold Damhauser.

There are many of the play manuscripts he wrote, four of them were translated into Javanese by Rini Tri Puspohardini and published entitled "Geng Toilet" (Publisher Literary Forum Surakarta, 2012). His other books "Leadership Roots Grass" was published by Yogja Bangkit Publisher in 2015, and "Anai-anai Darkened by Badai; Isolated ODHA Nelawan 
Stigma" (first printing) was published by Rumah Matahari Kudus together with the Sheep Indonesia Foundation Yogjakarta in 2015.

For the theater performances he had done, there were countless. Among them had performed the movement monologue "Sarong" at the Amphi Theater (Monbijoupark, Berlin, Germany), The Panda Club Theater (Cultur Braureire, Berlin, Germany), and Teater Besar of the Indonesian Art Institute Surakarta (2011), as well as at Cemara 6 Art Center. Jakarta (2012). Wrote plays and directed a colossal drama produced by the Kalam Kudus Foundation Surakarta entitled "Namaku Indonesia" (2013) and P "Pulanglah Nak" (2014), a Solo Batik Carnival production "Wahyu Tumurun" (2014) and "Sedulur Papat" (2015), as well as production of SMKI Surakarta "Kita Nusantara" (2017).

\section{Conclusion and Suggestion}

\subsection{Conclusion}

The hoax phenomenon at this time has become a matter of great concern and damage to common sense. The approach that has been relied on is the general approach. In fact, the practice of a legal approach presupposes a truly integrative law enforcer, and it still becomes a hope in this country. So, a cultural approach is needed to invite the community to fight hoaxes. By examining Sosiawan Leak's struggles in the Indonesian literary field and revealing world views of his thoughts as outlined in the Hoax Poetry Anthology can invite the community to fight hoaxes with a different approach, namely a cultural approach.

\subsection{Suggestion}

It is necessary to develop research on the object studied or there is a need for other variants of research related to the theory studied. On the object studied, for example, it can be examined again by using the method of genetic structuralism by utilizing the theory of the arena cultural production.

\section{References}

[1] Alif.id. 2018.Muktamar Sastra 2018: Menggali Kenusantaraan Membangun Kebangsaan.Muktamar Sastra 2018: Menggali Kenusantaraan Membangun Kebangsaan - Alif.ID.

[2] Aryanto, A., Sudardi, B., Purwasito, A., \& Wakit, A. (2017). Social Criticism in the Text Scripture of Dharmasonya. Komunitas: International Journal of Indonesian Society and Culture, 9(1), 70-80.

[3] Batool, A., Naheed, R., Khalid, A., Khan, A. B., \& Muhammad, S. A. A. (2015). Stylistic analysis of Alfread Tennyson's poem tears idle tears. International Journal of Multidisciplinary Research and Development, 2(3), 194-196.

[4] Detik,com. 2014. Cerita Sahabat di Solo Tentang Perubahan Wiji Thukul Setelah Jadi Aktivis. $\quad$ https://news.detik.com/berita/d-2624481/cerita-sahabat-di-solo-tentangperubahan-wiji-thukul-setelah-jadi-aktivis

[5] Deveson, A. (2017). The Limits of Cosmopolitanism in the Poetry of Michael. Hofmann. Concentric: Literacy \& Cultural Studies, 43(1). 
[6] Leak, Sosiawan. 2018. Antologi Sajak Hoax. Surakarta: Forum Sastra Surakarta.

[7] Rahayu,Dwi. 2016.Tularkan Ilmu Sastra, Sosiawan Leak Latih Baca dan Tulis Puisi. Tularkan Ilmu Sastra, Sosiawan Leak Latih Baca dan Tulis Puisi (bloktuban.com)

[8] Riadi, S., \& Emzir, E. (2015). Sufistic and Transformative Pedagogic Values in Syaikh Siti Jenar Novel by Agus Sunyoto Genetic Structuralism. IJLECR-INTERNATIONAL JOURNAL OF LANGUAGE EDUCATION AND CULTURE REVIEW, 1(1), 79-86.

[9] Shaikh, N. U. (2016). Literary Theory and Criticism: An Unaffordable Buzzword in English Literature?. International Journal of Applied Linguistics and English Literature, 5(3), 226-236.

[10] Siswantoro, 2010. Metode Penelitian Sastra. Analisis Struktur Puisi. Yogyakarta: Pustaka Pelajar.

[11] Teras lampung.com. 2014. Sosiawan Leak: 'Panglima' Pusi Menolak Korupsi.https://www.teraslampung.com/sosiawan-leak-panglima-pusi-menolak/

[12] Yogyakarta Kompas.com. 2018. Tokoh Lintas Agama Doakan 17 Pataka Merah Putih Kirab Satu Negeri. https://yogyakarta.kompas.com/read/2018/10/21/22245811/tokohlintas-agama-doakan-17-pataka-merah-putih-kirab-satu-negeri 